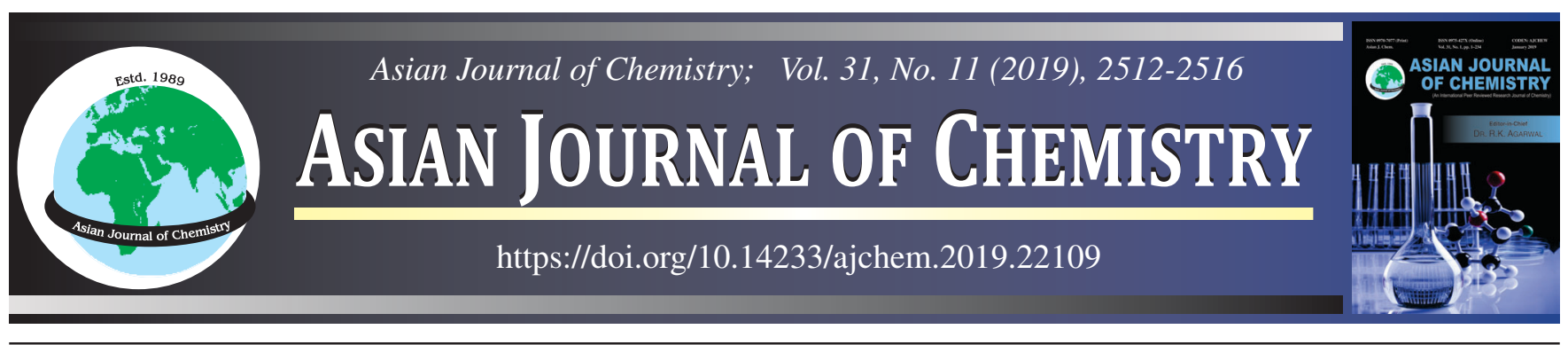

\title{
Extraction, Radical Scavenging and Antimicrobial Activity of Essential Oils of Root of Dryopteris marginalis
}

\author{
Md. Zahidul Islam ${ }^{1, \bullet}$, Jannat Al Foisal ${ }^{2}$, Mahbubur Rahman $^{2,3, *}$, Mst. Afsana Mimi, ${ }^{4, \bullet}$, Faridul Islam ${ }^{5, \bullet}$, \\ Rasel Habib $^{2, \bullet}$, Nowshin Farzana Khan ${ }^{6}$, Md. Atiqur Rahman ${ }^{4}$, Tanzima Parvin ${ }^{4}$ and Daxiang Cui, ${ }^{3,0}$
}

${ }^{1}$ Department of Chemistry, Sakarya University, 54187 Esentepe, Sakarya, Turkey

${ }^{2}$ Department of General Educational Development (GED), Faculty of Science and Information Technology, Daffodil International University, 4/2, Shukrabad, Mirpur Road, Dhanmondi, Dhaka 1207, Bangladesh

${ }^{3}$ Institute of Nano Biomedicine and Engineering, Shanghai, Engineering Research Center for Intelligent Instrument for Diagnosis and Therapy, Department of Instrument Science \& Engineering, School of Electronic, Information and Electrical Engineering, Shanghai Jiao Tong University, Shanghai 200240, PR China

${ }^{4}$ Department of Applied Chemistry \& Chemical Engineering, Faculty of Engineering \& Technology, Islamic University, Kushtia-7003, Bangladesh ${ }^{5}$ IFST, Bangladesh Council of Scientific and Industrial Research (BCSIR), Dhaka-1205, Bangladesh

${ }^{6}$ Department of Biotechnology and Genetic Engineering, Faculty of Engineering \& Technology, Islamic University, Kushtia-7003, Bangladesh

*Corresponding author: Tel/Fax: +88 029138234 (ext: 232); E-mail: mahbub_iuchem@yahoo.com

Received: 30 May 2019; Accepted: 7 June 2019;

Published online: 28 September 2019;

AJC-19578

The aim of the study was to characterize the chemical constituents and determine antibacterial and antioxidant activities of essential oils and three different extracts of Dryopteris marginalis. The root had essential oil yield of $0.36 \%$ (w/w) in which 12 organic compounds representing $97.22 \%$ of the root oils were identified. Tyranton was found as the most abundant component with $77.571 \%$ of the total concentration in the essential oil. The zones of inhibition of different organic extracts against the tested bacteria were found in the range of 6.5-15 mm. Pseudomonas was the most vulnerable with MICs of $15.62 \mu \mathrm{g} / \mathrm{mL}$ by both ethyl acetate and petroleum ether extract producing $3.8 \mathrm{~mm}$ zone of inhibition. The essential oils extracted from roots of Dryopteris marginalis showed maximum $85.29 \%$ inhibition of radical scavenging at $2 \mathrm{mg} / \mathrm{mL}$ concentration. Among all root extracts, methanol extract exhibited $41.11 \%$ inhibition at $2 \mathrm{mg} / \mathrm{mL}$ concentration.

Keywords: Essential oil, Dryopteris marginalis (L.), Radical scavenging, Antimicrobial activity, Alternative drug.

ᄂ - - - - - - - - - - - - - - - - - - - - - - - - - - -

\section{INTRODUCTION}

In the technological revolution era, still $80 \%$ people of the world depend on conventional sources for health remedy purposes [1]. The use of artificial agents became popular but it also brought the safety issues in front as many studies showed some respiratory tract and other health risks [2]. This is why, natural constituents are still considered trustworthy [3]. It is believed that nature may have the solution to even some incurable diseases [4]. Plants are comprised of different constituents including essential oil which can be used in different purposes. Essential oils are extracted from medicinal plants and confided to impart antimicrobial and antioxidant activities [5]. Although the presence of microbes has been discovered recently but various plants were used against them even before knowing the activity
$[6,7]$. Essential oils extracted from different sources have found their use in protection of food from microbial contamination, treatment in various diseases, perfumery, cosmetics, sanitary purposes, etc. [8-10]. But there are a number of resources which are still waiting to be revealed. Thus, extraction of essential oils from different natural resources has allured the attention and still has the room to discover new components with potential [11]. Among them different species of Dryopteris fern have shown promising results against various microbes.

There are about 250 species of Dryopteris fern available in different parts of Asia [12]. These ferns are favoured by the tropical weather and damp shady places, this is why it can be found in almost every corner of Bangladesh. Different investigations have showed that Dryopteris ferns contain variety of essential oils and show different activities against some specific

This is an open access journal, and articles are distributed under the terms of the Attribution 4.0 International (CC BY 4.0) License. This license lets others distribute, remix, tweak, and build upon your work, even commercially, as long as they credit the author for the original creation. You must give appropriate credit, provide a link to the license, and indicate if changes were made. 
microorganisms. Previous studies have suggested that different species can be used as anthelmintic medicine [13], antipyretics [14], anticonvulsant, anti-rheumatic drugs, leprostatic agents [15], anti-tumour and immunomodulatory agents [16]. Other studies also indicated that some of the species of Dryopteris has already been used as anti-venom and healing snake bite wounds [17] and in the treatment of schistosomiasis [18]. A report published by Hill [19] in 1937, confirmed the presence of 'filicin' which can be used as a worm expellant.

Dryopteris marginalis is known as the marginal shield fern or marginal wood fern which is very common and available all over Bangladesh. In the present study, the chemical composition of the essential oil obtained from roots and determined anti-bacterial activity from three different extracts of roots. This study also indicates the antioxidant activities of essential oil and various organic extracts with emphasis for the possible future use of the essential oil and extracts of Dryopteris marginalis. To the best of our knowledge, no report has been published on the analysis of root of Dryopteris marginalis species yet.

\section{EXPERIMENTAL}

Plant material: Healthy, disease free plant samples were collected from Atghoria, Pabna district and Islamic University, Kushtia campus of Bangladesh in January 2015 and the species was identified by the Department of Botany, University of Dhaka, Bangladesh. The collected plants were separated from undesirable materials or plant parts and then were washed with deionized water, then they were shade-dried for four weeks. The roots were then collected and ground into coarse powder by a grinder. In an air proof container, the powder was placed and stored in low temperature and dry place till further analysis.

Extraction of essential oil: The essential oil was extracted according to the method described by Viuda-Martos et al. [20] with some modifications. Briefly, the air dried roots (200 g) were hydrodistilled for 3,3 and $4 \mathrm{~h}$ respectively using a Clevengertype apparatus. The oily layer acquired on top of the aqueous distillate was separated and dried with anhydrous sodium sulfate. The oil acquired was stored in tightly sealed dark vials and covered with aluminum foil at $4{ }^{\circ} \mathrm{C}$ until further analysis.

Gas chromatography-mass spectrometry (GC-MS) analysis: Hewlett Packard 6890 gas chromatography was used for analysis of essential oils. In the GC-MS, HP-5 MS capillary column which is $30 \mathrm{~m} \times 0.25 \mathrm{~mm}$ (crosslinked phenyl-methyl siloxane) in dimension and $0.25 \mu \mathrm{m}$ of film thickness was used and was equipped with a Hewlett Packard 6890 mass selective detector. As a carrier gas helium was used in the system. Different conditions of chromatographer like ion source, ionization energy and electron current were $230^{\circ} \mathrm{C}, 70 \mathrm{eV}$ and $2 \mathrm{~A}$, respectively. The temperature of column was set for $40^{\circ} \mathrm{C}$ for the first $5 \mathrm{~min}$ and then it was increased to $280^{\circ} \mathrm{C}$ at a rate of $10^{\circ} \mathrm{C} / \mathrm{min}$. The retention indices were calculated for all volatile constituents using a homologous series of $\mathrm{C}_{8}-\mathrm{C}_{22} n$-alkanes. The constituents were identified either with the comparison of the identical retention indices to literature [21] or comparing the mass spectra stored in Wiley mass spectral database (Hewlett Packard, Vienna, Austria). The relative proportion (\%) was also identified for each volatile compound.
Preparation of organic extracts: Each $15 \mathrm{~g}$ of root powder was weighed with the electrical balance and transferred into three separate $150 \mathrm{~mL}$ conical flasks. Then $75 \mathrm{~mL}$ of methanol, ethyl acetate and petroleum ether was added in each flask respectively and placed on a shaker at room temperature for 7 days. The crude extracts were then filtered by passing the extracts through Whatman no. 1 filter paper and the solvents were evaporated by vacuum rotary evaporator at $45{ }^{\circ} \mathrm{C}$. After that the extracts were diluted to $7.81,15.62,31.25,62.5,125,250,500$, $1000 \mu \mathrm{g} / \mathrm{mL}$. All the extracts were stored in refrigerator at $4^{\circ} \mathrm{C}$ in sterile for further use [22].

Microbial strains and culture: Different microorganism strains were provided by Bangladesh Council of Scientific and Industrial Research (BCSIR), Rajshahi, Bangladesh and Department of Biotechnology and Genetic Engineering, Islamic University, Kushtia, Bangladesh. The antimicrobial activity of essential oil was tested against five different microorganisms. Among them, Staphylococcus aureus and Bacillus cereus were Grampositive strains while Salmonella typhi, Pseudomonas and $E$. coli were Gram-negative bacteria. All the strains were stored in their appropriate agar slants at $4^{\circ} \mathrm{C}$ and cultured at $37^{\circ} \mathrm{C}$ on nutrient agar or nutrient broth mediums.

Antimicrobial bioassay: in vitro Antimicrobial activities of the test samples were carried out by disc diffusion method [23-25]. Filter paper discs (5 mm diameter) of various extract (methanol, ethyl acetate, petroleum ether) were prepared by impregnating blank sterile paper discs to the respective extracts with different concentrations $(7.81,15.62,31.25,62.5,125$, 250,500 and $1000 \mu \mathrm{g} / \mathrm{mL}$ ) and residual solvents were completely evaporated. Discs containing the test materials were placed on nutrient agar medium uniformly seeded with the test bacteria. Standard discs of kanamycin $(10 \mu \mathrm{g} / \mathrm{discs})$ and blank discs (impregnated with solvents followed by evaporation) were used as positive and negative control respectively. These plates were then kept at low temperature $\left(4^{\circ} \mathrm{C}\right)$ for $24 \mathrm{~h}$ to allow maximum diffusion of test samples and then incubated at $37^{\circ} \mathrm{C}$ for $24 \mathrm{~h}$ to allow maximum growth of the bacteria. The antibacterial activity of the test agents was determined by measuring the diameter of zone of inhibition in millimeter. Each assay in this experiment was replicated three times. Minimum inhibitory concentration (MIC) values of the extracts showing significant results (methanol and ethyl acetate extract) were determined in the present study following the serial dilution technique [26].

Minimum inhibitory concentration (MIC): Minimum inhibitory concentrations (MICs) of essential oils from different extracts of ethyl acetate, petroleum ether and methanol were tested by the methods described by Gur et al. [27] with slight modification. The cultured bacterium was taken into the screw cape tubes. Deionized water $(10 \mathrm{~mL})$ was added to the screw caped tube and whirled the mixture for homogenous mixing. This suspension was used as inoculums. The optical density (OD) was measured with the colorimeter and an optical density of $10^{6}$ to $10^{8} \mathrm{CFU} / \mathrm{mL}$ for the test organisms was confirmed. For the determination of MIC, nutrient broth medium was prepared by using peptide digest of animal tissue $5 \mathrm{~g} / \mathrm{L}$, sodium chloride $1.5 \mathrm{~g} / \mathrm{L}$, beef extract $1.5 \mathrm{~g} / \mathrm{L}$, yeast extract $1.5 \mathrm{~g} / \mathrm{L}$ and distilled water $1000 \mathrm{~mL}$. For the test, $13 \mathrm{~g} / 1000 \mathrm{~mL}$ of nutrient broth media was taken in a conical flask. The media was properly 
TABLE-1

CHEMICAL COMPOSITION OF THE ESSENTIAL OIL ISOLATED FROM THE ROOT OF D. marginalis

\begin{tabular}{clccc}
\hline \multicolumn{1}{c}{ Compound name } & Molecular weight (mw) & Retention index (RI) & Peak area (\%) \\
\hline 1 & 3-Ethyl-3-buten-2-one & 98 & 721 & 0.924 \\
2 & Methacide & 92 & 794 & 8.273 \\
3 & 4-Hydroxy-2-pentanone & 102 & 845 & 2.177 \\
4 & Tyranton & 116 & 995 & 77.571 \\
5 & Iso-octyl alcohol & 130 & 1304 & 0.399 \\
6 & Tridecene & 182 & 1365 & 0.795 \\
7 & Pyrimidine-2,4(1H,3H)-dione-5-amino-6-nitroso & 156 & 2017 & 0.597 \\
8 & 9-Eicosene & 280 & 2255 & 1.093 \\
9 & Pentanoic acid & 306 & 2315 & 2.938 \\
10 & Muscalure & 332 & 2423 & 1.270 \\
11 & Di chloro acetic acid & 366 & 2455 & 0.923 \\
12 & 2,6-Bis $(t$-butyl)-4-(di-methyl benzyl) phenol & 324 & Total & 3.260 \\
\hline
\end{tabular}

dissolved with the distilled water and then sterilized in an autoclave for $15 \mathrm{~min}$ with $121^{\circ} \mathrm{C}$ and $15 \mathrm{lbs} / \mathrm{inch}^{2}$ pressure. After autoclaving the media was cooled for some time and poured into the autoclaved screw cap tubes in the laminar air flow cabinet. It was then ready for inoculation of microorganism with different concentration of extracts.

DPPH assay: On the basis of the scavenging activities of stable 2,2-diphenyl-1-picrylhydrazyl (DPPH, Sigma-Aldrich, St. Louis, USA) free radical, the DPPH radical scavenging activity of the essential oil and extracts was measured [28]. Various concentrations of test extracts $(0.1 \mathrm{~mL})$ were added to $2.9 \mathrm{~mL}$ of $0.004 \%(\mathrm{w} / \mathrm{v})$ methanol solution of DPPH. The incubation period was $30 \mathrm{~min}$ at room temperature and at $517 \mathrm{~nm}$, the absorbance was monitored against a blank. Inhibition percent of free radical of DPPH (I \%) was calculated as follows:

$$
I(\%)=\frac{A_{\text {blank }}-A_{\text {sample }}}{A_{\text {blank }}} \times 100
$$

where $A_{\text {blank }}$ is the absorbance of the control reaction (containing all reagents except the test compound) and $\mathrm{A}_{\text {sample }}$ is the absorbance of test compound.

Statistical analysis: Each experiment was run in triplicate and main values were calculated with SD (standard deviation). One-way analysis of variance (ANOVA) and Duncan's multiple range tests were carried out to determine significant differences $(p<0.05)$ between the means by SPSS version 11.0 and EXCEL program.

\section{RESULTS AND DISCUSSION}

Chemical composition of the essential oils: The hydrodistillation of roots of $D$. marginalis gave the golden yellow oil with yield of $0.36 \%(\mathrm{w} / \mathrm{w})$. Composition identification was confirmed by comparing the data obtained from the samples used in this study with the result reported by Adams [21]. GCMS analysis of the essential oil led to the identification of 12 compounds, representing $97.22 \%$ of the total oil. The detected major compounds were tyranton $(77.571 \%)$, methacide (5.273\%), 2,6-bis(t-butyl)-4-(dimethyl benzyl) phenol (3.260 $\%)$, pentanoic acid (2.938\%), 4-hydroxy-2-pentanone $(2.177$ $\%$ ) and muscalure $(1.270 \%)$. The identified compounds are listed in Table- 1 according to their elution order.

Antimicrobial activity: The antimicrobial activity of different extracts of roots of Dryopteris marginalis is shown in Table-2 in a comparative way with standard antibiotic disckanamycin $(10 \mu \mathrm{g} / \mathrm{discs})$. The observation of this study stated that, the extract from methanol showed the highest zone of inhibition of $12 \mathrm{~mm}$ against $S$. aureus followed by $15 \mathrm{~mm}$ and $10 \mathrm{~mm}$ against $E$. coli and $B$. cereus, respectively. The extract from ethyl acetate produced satisfactory sensitivity of 9.6, 9.7, 6.5 and $7 \mathrm{~mm}$ against E. coli, Pseudomonas, B. cereus and $S$. aureus, respectively whereas petroleum ether extracts possessed relatively poor antibacterial activity. All the extracts were somehow effective against $E$. coli, B. cereus and $S$. aureus whereas $S$. typhi was completely resistant against all extracts but Pseudomonas was partially prohibitive against the methanol extract. Positive control produced significant zones of inhibition contrary to all the tested bacteria while no zone was formed by negative control. In comparison to antibiotic, though the activity of different extracts of roots of Dryopteris marginalis was very close to kanamycin, but the availability, ease in extraction and comparative low cost refer it as a potential antibiotic candidate.

\begin{tabular}{lcccc}
\multicolumn{5}{c}{ TABLE-2 } \\
\multicolumn{5}{c}{ ANTIBACTERIAL ACTIVITIES OF THREE } \\
DIFFERENT ROOT EXTRACTS OF D. marginalis \\
\hline \multirow{2}{*}{$\begin{array}{c}\text { Tested } \\
\text { bacteria }\end{array}$} & $\begin{array}{c}\text { Kanamycin } \\
(10 \mu \mathrm{g})\end{array}$ & $\begin{array}{c}\text { Ethyl } \\
\text { acetate }\end{array}$ & $\begin{array}{c}\text { Petroleum } \\
\text { ether }\end{array}$ & Methanol \\
\cline { 2 - 5 } & 19 & 9.6 & 8.8 & 15 \\
\hline E. coli & 21 & 9.7 & 9.3 & - \\
Pseudomonas & 19 & - & - & - \\
S. thyphi & 19 & 6.5 & 7 & 12 \\
S. aureus & 20 & 7 & 7 & 10 \\
B. cereus & & & & \\
\hline
\end{tabular}

Minimum inhibitory concentration: MIC values of various extracts were found between 7.81-1000 $\mu \mathrm{g} / \mathrm{mL}$. The best MIC value was observed $15.62 \mu \mathrm{g} / \mathrm{mL}$ against Pseudomonas by both ethyl acetate and petroleum ether extract producing $3.8 \mathrm{~mm}$ zone of inhibition while $S$. typhi showed complete resistance within the range against all extracts (Table-3). In case of $E$. coli, methanol extract showed comparatively good result (MIC value $62.5 \mu \mathrm{g}$ / $\mathrm{mL}$ ) than the other two extract (125 and $250 \mu \mathrm{g} / \mathrm{mL}$, respectively in petroleum ether and ethyl acetate extracts). S. aureus and $B$. cereus exhibited similar type of result in both ethyl acetate and petroleum ether extract. In both extracts, the MIC value was 125 $\mu \mathrm{g} / \mathrm{mL}$. But the previous one showed MIC value of $31.25 \mu \mathrm{g} / \mathrm{mL}$ whereas B. cereus showed that of $62.5 \mu \mathrm{g} / \mathrm{mL}$ in methanol extract. 

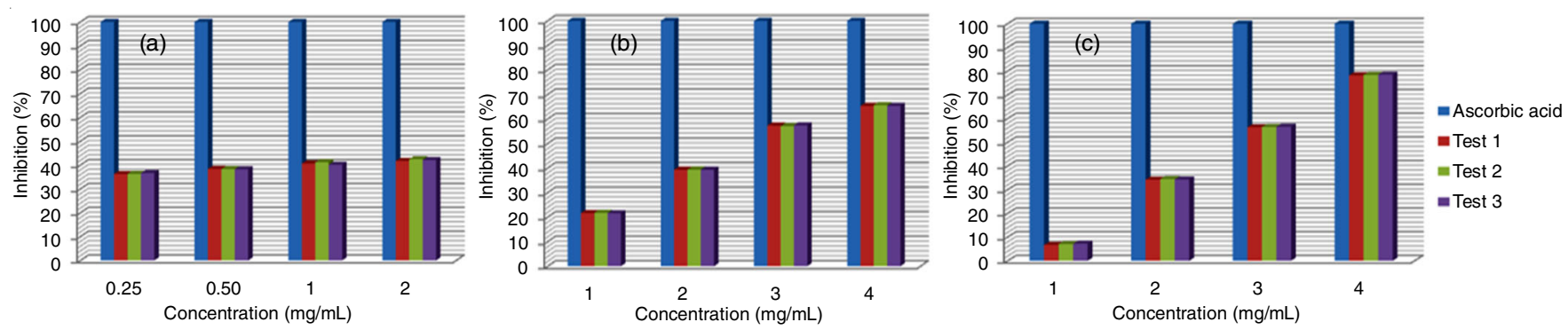

Fig. 1. DPPH radical scavenging activities of (a) methanol extract, (b) ethyl acetate root extracts, (c) petroleum ether root extracts of D. marginalis

\begin{tabular}{lccc}
\hline \multicolumn{4}{c}{ TABLE-3 } \\
\begin{tabular}{|ccc} 
LIST OF MINIMUM INHIBITORY CONCENTRATION \\
FOR DIFFERENT TESTED BACTERIA
\end{tabular} \\
\hline Tested bacteria & $\begin{array}{c}\text { Ethyl acetate } \\
\text { extract } \\
(\mu \mathrm{g} / \mathrm{mL})\end{array}$ & $\begin{array}{c}\text { Petroleum } \\
\text { ether extract } \\
(\mu \mathrm{g} / \mathrm{mL})\end{array}$ & $\begin{array}{c}\text { Methanol } \\
\text { extract } \\
(\mu \mathrm{g} / \mathrm{mL})\end{array}$ \\
\hline E. coli & 250 & 125 & 62.5 \\
Pseudomonas & 15.62 & 15.62 & $>1000$ \\
S. thyphi & $>1000$ & $>1000$ & $>1000$ \\
S. aureus & 125 & 125 & 31.25 \\
B. cereus & 125 & 125 & 62.5 \\
\hline
\end{tabular}

DPPH radical scavenging activities: Free radical scavenging properties of different extracts from roots of $D$. marginalis and essential oils are presented in Fig. 1. Higher percentage of inhibition value indicates higher antioxidant activity [29]. Essential oils extracted from roots showed higher scavenging ability of DPPH radicals of $85.29 \%$ inhibition at $2 \mathrm{mg} / \mathrm{mL}$ concentration (Fig. 2) when compared to those of various extracts of D. marginalis showing maximum inhibition around $40 \%$ at the same concentration.

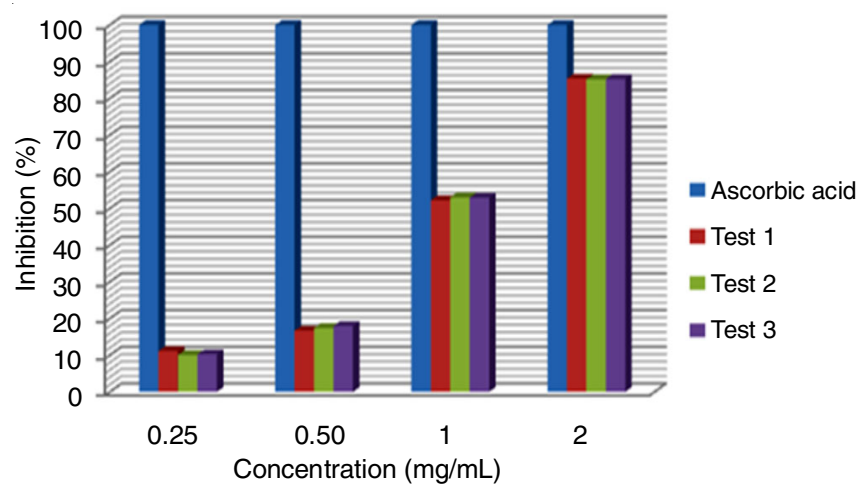

Fig. 2. DPPH radical scavenging activities of root essential oils of $D$. marginalis

Likewise, among all root extracts, methanolic extract showed significant antioxidant property of $41.11 \%$ inhibition at the concentration of $2 \mathrm{mg} / \mathrm{mL}$ (Fig. 1a). Ethyl acetate root extract exerted comparatively low radical scavenging activity around $39.05 \%$ inhibition at concentration of $2 \mathrm{mg} / \mathrm{mL}$ (Fig. 1b), whereas petroleum ether root extract showed the least radical scavenging activity of $33.8 \%$ inhibition at same concentration (Fig. 1c).

The antioxidative properties in natural sources have been reported to be mostly due to phenolic compounds [30-33] suggesting that root extracts exhibiting a promising antioxidant activity may be because of the presence of phenolic compounds.
The antioxidant property of extract of Dryopteris filixmas has been previously reported by Ali et al. [34]. According to them, the antioxidative activity of the extract of D. filixmas obtained by polar organic solvent (methanol) was greater than those of the extracts obtained by non-polar organic solvents (petroleum ether, chloroform). The present study indicated the similar antioxidative property of $D$. marginalis. Other studies showed that few species of fern such as $D$. affinis and rhizome of $D$. cochleata provided potent antioxidant activities $[35,36]$.

\section{Conclusion}

The outcome of present study suggests that the chemical composition of hydrodistilled oil obtained from root of Dryopteris marginalis representing 12 compounds containing $97.22 \%$ of total components, having oxygenated monoterpenes and sesquiterpene hydrocarbons and their oxygenated derivatives. These compounds have enormous potential to strongly inhibit microbial pathogens. The root extracts of Dryopteris marginalis were found to be effective against test bacteria, can be used as antibacterial agents in designing and developing new drugs. Further analysis of purification of active compounds of $D$. marginalis will provide a better understanding of the antibacterial mechanism.

\section{ACKNOWLEDGEMENTS}

The authors are grateful to Prof. Dr. M. Oliur Rahman, Department of Botany, University of Dhaka, Bangladesh for his expert opinion to detect $D$. marginalis species.

\section{CONFLICT OF INTEREST}

The authors declare that there is no conflict of interests regarding the publication of this article.

\section{REFERENCES}

1. C. Orwa, A Mutua, R. Kindt, R. Jamnadass and S. Anthony, Terminalia arjuna combretaceae (Roxb. ex DC.) Wight and Arn, Agroforestry Database 4.0 (2009).

2. C.L. Ye, D.H. Dai and W.L. Hu, Food Control, 30, 48 (2013); https://doi.org/10.1016/j.foodcont.2012.07.033.

3. Y. Zhang, X. Liu, Y. Wang, P. Jiang and S. Quek, Food Control, 59, 282 (2016); https://doi.org/10.1016/j.foodcont.2015.05.032.

4. G. Uddin, A. Rauf, T.U. Rehman and M. Qaisar, Middle East J. Sci. Res., 7, 707 (2011).

5. K. Carovic-Stanko, S. Orlic, O. Politeo, F. Strikic, I. Kolak, M. Milos and Z. Satovic, Food Chem., 119, 196 (2010); https://doi.org/10.1016/j.foodchem.2009.06.010.

6. S. Cosentino, C.I.G. Tuberoso, B. Pisano, M.L. Satta, V. Mascia, E. Arzedi and F. Palmas, Lett. Appl. Microbiol., 29, 130 (1999); https://doi.org/10.1046/j.1472-765X.1999.00605.x. 
7. J.L. Rios and M.C. Recio, J. Ethnopharmacol., 100, 80 (2005); https://doi.org/10.1016/j.jep.2005.04.025.

8. S.C. Joshi, A.R. Verma and C.S. Mathela, Food Chem. Toxicol., 48, 37 (2010); https://doi.org/10.1016/j.fct.2009.09.011.

9. T.S.A.T. Kamazeri, O.A. Samah, M. Taher, D. Susanti and H. Qaralleh, Asian Pac. J. Trop. Med., 5, 202 (2012); https://doi.org/10.1016/S1995-7645(12)60025-X.

10. B. Tepe, D. Daferera, A. Sokmen, M. Sokmen and M. Polissiou, Food Chem., 90, 333 (2005); https://doi.org/10.1016/i.foodchem.2003.09.013.

11. S. Burt, Int. J. Food Microbiol., 94, 223 (2004); https://doi.org/10.1016/j.ijfoodmicro.2004.03.022.

12. J.N. Mink, J.R. Singhurst and W.C. Holmes, Phytoneuron, 53, 1 (2010).

13. X. Han, Z. Li, C.Y. Li, W.N. Jia, H.T. Wang and C.H. Wang, Chem. Biodivers., 12, 1131 (2015); https://doi.org/10.1002/cbdv.201400157.

14. S.M. Vasuda, Ind. Fern. J., 16, 130 (1999).

15. M. Ali, S.A. Khan, A. Rauf, H. Khan, M.R. Shah, M. Ahmad, M.S. Mubarak and T. Ben Hadda, Med. Chem. Res., 24, 3218 (2015); https://doi.org/10.1007/s00044-015-1373-1.

16. X.J. Li, W. Wang, M. Luo, C.Y. Li, Y.G. Zu, P.S. Mu and Y.J. Fu, Food Chem., 133, 437 (2012); https://doi.org/10.1016/j.foodchem.2012.01.056.

17. Z.L. Zhao, C.H. Leng and Z.T. Wang, Planta Med., 73, 1230 (2007); https://doi.org/10.1055/s-2007-981588

18. L.G. Magalhães, G.J. Kapadia, L.R. da Silva Tonuci, S.C. Caixeta, N.A. Parreira, V. Rodrigues and A.A. da Silva Filho, Parasitol. Res., 106, 395 (2010); https://doi.org/10.1007/s00436-009-1674-8.

19. A.F. Hill, Economic Botony-A Text Book of Useful Plans and Plan Products, McGraw-Hill Book Company, Inc.: New York, London (1937).

20. M. Viuda-Martos, M.A. Mohamady, J. Fernández-López, K.A. Abd ElRazik, E.A. Omer, J.A. Pérez-Alvarez and E. Sendra, Food Control, 22, 1715 (2011); https://doi.org/10.1016/j.foodcont.2011.04.003.
21. R.P. Adams, Identification of Essential Oil Components by Gas Chromatography/Mass Spectroscopy, Allured publishing Co. Carol Stream: Illinois (1995)

22. A.N.M. Mamun-or-Rashid, M.R. Islam and B.K. Dash, Res. J. Med. Plant, 6, 334 (2012)

23. A.W. Bauer, W.M. Kirby, J.C. Sherris and M. Turck, Am. J. Clin. Pathol., 45(4_ts), 493 (1966); https://doi.org/10.1093/ajcp/45.4 ts.493.

24. J.H. Jorgensen, Performance Standards for Antimicrobial Disk Susceptibility Tests, Approved Standard NCCLS, p. 17 (1998).

25. M.A. Wikler, Methods for Dilution Antimicrobial Susceptibility Test for Bacteria that Grow Aerobically, Approved Standard M7-A8 (2009).

26. D. BK M. K. Sen and M. K. Alam, Am. J. Life Sci., 1, 113 (2013).

27. S. Gur, D. Turgut-Balik and N. Gur, World J. Agric. Sci., 2, 439 (2006).

28. D.J. Newman and G.M. Cragg, J. Nat. Prod., 70, 461 (2007); https://doi.org/10.1021/np068054v.

29. L.M. Cheung, P.C. Cheung and V.E. Ooi, Food Chem., 81, 249 (2003); https://doi.org/10.1016/S0308-8146(02)00419-3.

30. F. Hayase and H. Katoi, J. Nutr. Sci. Vitaminol. (Tokyo), 30, 37 (1984); https://doi.org/10.3177/jnsv.30.37.

31. M.I. Gil, F.A. Tomás-Barberán, B. Hess-Pierce, D.M. Holcroft and A.A. Kader, J. Agric. Food Chem., 48, 4581 (2000); https://doi.org/10.1021/jf000404a.

32. P. Goupy, C. Dufour, M. Loonis and O. Dangles, J. Agric. Food Chem., 51, 615 (2003); https://doi.org/10.1021/jf0259381.

33. D.G. Soares, A.C. Andreazza and M. Salvador, J. Agric. Food Chem., 51, 1077 (2003); https://doi.org/10.1021/jf020864z.

34. M.S. Ali, K. Mostafa, M.O. Raihan, M.K. Rahman, M.A. Hossain and M.S. Alam, Int. J. Drug Dev. Res., 4, 223 (2012).

35. H. Valizadeh, A. Sonboli, F. Mahmoodi Kordi, H. Dehghan and M.B. Bahadori, Pharm. Sci., 21, 18 (2015); https://doi.org/10.15171/PS.2015.12.

36. A. Kathirvel, A.K. Rai, G.S. Maurya and V. Sujatha, Int. J. Pharm. Pharm. Sci., 6, 179 (2014). 